Economia e Sociedade, Campinas, Unicamp. IE. http://dx.doi.org/10.1590/1982-3533.2020v30n1art03

\title{
Sistema de crédito e crises em Marx: o ciclo industrial e as suas fases *
}

\author{
Henrique de Abreu Grazziotin ** \\ Ronaldo Herrlein Jr. ${ }^{* * *}$
}

\begin{abstract}
Resumo
$\mathrm{O}$ artigo apresenta a teoria dos ciclos industriais de Marx, efetuando uma síntese e uma sistematização de sua abordagem sobre este tema, que se encontra fragmentada ao longo de diversos trechos da Seção V do Livro III de O Capital. A teoria dos ciclos industriais de Marx explica por que e como o sistema de crédito periodicamente impulsiona a produção capitalista a crises endógenas de superprodução e pânico financeiro. $\mathrm{O}$ artigo apresenta os elementos teóricos básicos necessários para a compreensão do sistema de crédito na abordagem de Marx, para posteriormente sistematizar a sua teoria, caracterizando cada fase do ciclo e indicando as causas dos movimentos observados a partir da dinâmica do crédito, que afeta diretamente a reprodução capitalista.
\end{abstract}

Palavras-chave: Marx, Karl, 1818-1883, Sistema de crédito, Crises, Ciclos industriais.

\section{Abstract \\ Credit system and crisis in Marx: the industrial cycle and its phases}

The article presents Marx's theory of the industrial cycle, making a synthesis and a systematization of his approach on this theme, which is fragmented throughout several sections of Section 5 of Volume III of Capital. Marx's theory of industrial cycles explains why and how the credit system periodically drives capitalist production to endogenous crises of overproduction and financial panic. The article presents the basic theoretical elements needed to understand the credit system in Marx's approach, to later systematize his theory, characterizing each phase of the cycle and indicating the causes of the movements observed from the credit dynamics, which directly affects capitalist reproduction.

Keywords: Marx, Karl, 1818-1883, Credit system, Crisis; Industrial cycles.

JEL B14, B51, E32, E43, E51.

\section{Introdução}

Este trabalho tem como objetivo apresentar uma síntese de parte da teoria econômica de Marx ainda pouco explorada na literatura econômica, que trata da existência de ciclos nos quais o sistema de crédito periodicamente impulsiona a produção capitalista a crises. Trata-se de uma teoria de crises endógenas impulsionadas pelo crédito e que têm como resultados periódicos superprodução e pânico financeiro. Esses ciclos são chamados por Marx de Ciclos Industriais. Sua abordagem sobre este tema está fragmentada ao longo dos seus escritos, podendo ser encontrada em diversos trechos da Seção V do Livro III de $O$ Capital, junto à descrição de Marx dos elementos constitutivos do Sistema de

${ }^{*}$ Artigo recebido em 24 de julho de 2018 e aprovado em 23 de abril de 2020.

** Doutorando em Economia do Desenvolvimento pelo Programa de Pós-Graduação em Economia da Universidade Federal do Rio Grande do Sul (PPGE-UFRGS), Porto Alegre, RS, Brasil. E-mail: henrique.grazziotin@gmail.com. ORCiD: https://orcid.org/00000001-8219-2250.

${ }^{* * * *}$ Professor do Programa de Pós-Graduação em Economia da Universidade Federal do Rio Grande do Sul (PPGE-UFRGS), Porto Alegre, RS, Brasil. E-mail: ronaldoh@ufrgs.br. ORCiD: https://orcid.org/0000-0002-9613-8068. 
Crédito e de sua crítica às concepções do Currency Principle e da Banking School. Por essa exposição fragmentada, em escritos publicados postumamente por Engels, aos quais não foi dada redação final por Marx e num formato que dificulta a sua apreensão, faz-se necessário um trabalho de síntese e de sistematização do que seria a concepção de Marx sobre esse assunto. Neste artigo, procuramos realizar esta tarefa, vinculando a explicação da ocorrência dos ciclos industriais aos elementos teóricos pertinentes ao sistema de crédito.

A teoria dos ciclos industriais tem sido, até agora, pouco explorada na literatura marxista. Cipolla (1997) faz uma breve interpretação do ciclo de Marx e analisa a interpretação de diversos autores, como Itoh (1980, 1988), Lianos (1987), Crotty (1987), Weeks (1981), Sherman (1991) e Foley (1986), concluindo que a literatura marxiana sobre ciclos econômicos, crise e taxas de juros não leva em consideração diversas proposições de Marx sobre o assunto, sendo necessária uma consideração mais minuciosa da parte V do Livro III de $O$ Capital. Destaca-se como uma exceção a essa regra o trabalho de Harvey (2013, p. 393-398), em que o autor busca sintetizar a concepção de Marx acerca das fases dos ciclos industriais, assim como faremos neste trabalho, porém sem o mesmo nível de detalhamento e aprofundamento teórico: "A representação de Marx pode ser reconstruída a partir de uma leitura atenta do terceiro livro de $O$ capital (capítulos 26 a 35). O processo de acumulação passa por várias fases de estagnação, recuperação, expansão baseada no crédito, febre especulativa e crash" (Harvey, 2013, p. 393).

A dificuldade de apropriação da teoria de Marx se explica por diversos motivos: em primeiro lugar, os textos de Marx que apresentam estes elementos teóricos não apresentam redação final, acabada para publicação. As partes necessárias para a sua compreensão plena estão, em certa medida, fragmentadas e embaralhadas. Em segundo lugar, a descrição dos ciclos industriais de Marx está muito associada à experiência histórica da Inglaterra no Século XIX. Sem compreender os processos históricos por ele analisados, o entendimento da sua teoria dos ciclos industriais também se torna parcialmente comprometido. Por fim, outro fator é a relação direta que os ciclos mantêm com o sistema de crédito. Sem compreendê-lo, as determinações de cada fase do ciclo dificilmente podem ser compreendidas, pois são decorrências dele. Dessa forma, a sistematização e organização da concepção teórica de Marx requer um esforço de revisão e detalhamento bastante alto. Neste trabalho, procuramos resolver em parte esses problemas ao sintetizar os elementos teóricos dispersos nos seus escritos e relacioná-los com o sistema de crédito, facilitando a apreensão e o debate acerca desta parte da teoria de Marx, que é essencial para o entendimento das crises financeiras.

Assim, este artigo está estruturado da seguinte forma: após esta introdução, buscaremos apresentar brevemente os elementos teóricos básicos necessários para a compreensão do sistema de crédito na abordagem de Marx. Posteriormente, apresentaremos a sistematização da teoria do ciclo industrial de Marx, caracterizando cada fase do ciclo e indicando as causas dos movimentos observados a partir da dinâmica do crédito, que afeta diretamente a reprodução capitalista. Segue-se uma breve conclusão.

\section{Dinheiro e sistema de crédito em Marx}

Tendo-se como base a teoria econômica de Marx, o dinheiro em sua forma concreta, real, é um fenômeno complexo, uma vez que existem diversas determinações ao qual o mesmo está 
submetido, decorrentes das diversas relações que se formam no âmbito do modo de produção capitalista. Nos termos do método da Economia Política exposto por Marx (2011), para se chegar à compreensão plena de fenômenos sociais complexos, dotados de múltiplas determinações, é necessário reconstruir, no âmbito da abstração, as diversas categorias e relações existentes, indo das mais simples, basilares dos fenômenos, às mais complexas, que são aquelas cuja existência depende das anteriores. Nesse sentido, é possível transpor, a partir da abstração, a aparência dos fenômenos concretos, na qual os mesmos aparecem como um emaranhado de relações simultâneas e difusas, para a essência dos fenômenos, a partir da qual se pode entender o concreto como um todo mediado racionalmente por suas diversas determinações.

Dessa maneira, para que se possa entender o que é o dinheiro para Marx, as diversas relações às quais o mesmo está submetido e como emerge, no modo de produção capitalista, um sistema de crédito que é capaz de levar a produção periodicamente a crises, é necessário reconstruir as diversas determinações do dinheiro tratadas por Marx ao longo de O Capital. Podemos citar quatro conjuntos de determinantes tratados por Marx em relação ao dinheiro: (i) Dinheiro enquanto forma da mercadoria, como categoria que emerge da circulação da produção na relação mercantil, ou seja, da forma mercadoria da produção (Livro I); (ii) Capital-dinheiro: dinheiro enquanto forma assumida pelo capital em seu processo de circulação (Livro II); (iii) Capital portador de Juros: capital-dinheiro de empréstimo, em que o Capital assume a forma de Mercadoria Capital (Livro III); e (iv) Capital Fictício, Sistema de Crédito e Dinheiro de Crédito: determinações decorrentes da emergência do crédito comercial, do capital bancário, do Mercado de Ações, do capital fictício, etc. (Livro III). Buscaremos citar sinteticamente os principais aspectos de cada um destes determinantes, sem proceder ao detalhamento necessário para compreendê-los integralmente, o que pode ser verificado no próprio Marx (2012; 2014a; e 2014b) e em De Brunhoff (1976), Germer (1997), entre outras diversas referências que tratam desse tema ${ }^{1}$.

O primeiro determinante é o da circulação simples de mercadorias. Essa determinação não é estrita do modo de produção capitalista, mas sim da circulação mercantil, quando a produção assume a forma mercadoria e circula nessa forma. Marx demonstra como, no processo de trocas de mercadorias, surge uma mercadoria que cumpre a função de equivalente geral, como autonomização do valor das mercadorias. Essa mercadoria se torna "materialização uniforme e social de trabalho humano homogêneo" (Marx, 2012, p. 136). Historicamente, as mercadorias que assumem a forma dinheiro são os metais preciosos, como ouro e prata, pois suas propriedades físicas convergem com as necessidades sociais decorrentes da autonomização do valor.

Ao assumir a forma dinheiro, essa mercadoria cumpre uma série de funções necessárias para a circulação mercantil: (i) na função de medida do valor, as demais mercadorias têm o seu valor expresso, relativamente ao valor do dinheiro, na forma preço. Para isso, estabelece-se um padrão de preços, no qual quantidades físicas de dinheiro são igualadas a determinada unidade monetária; (ii) na função de meio de circulação, o dinheiro media as trocas, separando a necessidade de compras e vendas simultâneas existente na troca simples e resolvendo a contradição inerente às mercadorias

(1) Em relação a Germer (1997), o argumento de nossa exposição é semelhante, no sentido de compreender que a teoria em Marx sobre o dinheiro está estruturada nas determinações decorrentes (i) da esfera da circulação das mercadorias, (ii) da esfera da produção capitalista, na qual o capital é o conceito central e distingue-se do dinheiro, e (iii) da esfera do crédito, na qual se desenvolve o dinheiro de crédito. 
entre valor de uso e valor ${ }^{2}$. Nessa função, o dinheiro cunhado por determinado Estado nacional assume a forma de moeda, circulando em determinada esfera nacional e podendo ser substituído por símbolos de dinheiro; (iii) na função de entesouramento, a circulação do dinheiro é interrompida, assumindo o dinheiro a forma de tesouro e seu possuidor, a função de entesourador. O dinheiro é entesourado para suprir a necessidade de compras e pagamentos fortuitos, mas também como acúmulo da forma pura do valor. Além disso, essa função possibilita o ajuste endógeno da quantidade de meio circulante, através da mudança de forma do dinheiro entre moeda e tesouro; (iv) na função de meio de pagamento, passa a surgir a separação temporal entre a alienação da mercadoria e a realização do seu preço, ou seja, a separação entre aquisição e pagamento. Assim, quando é realizado o pagamento de uma mercadoria em período posterior à aquisição, o dinheiro cumpre a função de meio de pagamento. $\mathrm{O}$ vendedor assume a função de credor e o comprador, a função de devedor, criando-se a figura da dívida, ou seja, de direito sobre dinheiro a receber. Sobre essa função, alicerçase o desenvolvimento do dinheiro de crédito e do sistema de crédito, através da circulação e da compensação de dívidas; (v) por fim, o dinheiro assume a função de dinheiro mundial, na qual se despe de sua roupagem de moeda ou símbolos de valor nacionais para cumprir as funções de meio universal de compra e pagamentos e de encarnação absoluta da riqueza. Os países devem manter dinheiro mundial em reserva para o comércio internacional e para pagamentos e liquidação de débitos internacionais.

O segundo determinante é o da circulação do capital. Com a emergência do capital industrial e da produção na forma capitalista, o dinheiro que circula como capital é capital-dinheiro, forma dinheiro do capital, e assume funções específicas na sua circulação que decorrem do fato de ser capital, e não especificamente de sua forma dinheiro. Ao longo da circulação do capital industrial, formam-se fundos de reserva, tesouros decorrentes da função de entesouramento do dinheiro, existindo como capital-dinheiro latente que acompanha transitoriamente a circulação do capital, cumprindo nela funções técnicas específicas do capital, relacionadas com as etapas do seu ciclo. Os fundos monetários de reserva de que trata Marx estão relacionados ao ciclo do capital industrial (fundo de meios de compras e de meios de pagamento, fundo de acumulação e fundo de reservas), à rotação do capital fixo (fundo de depreciação) ou do capital circulante (fundo de capital adicional liberado) e à circulação da renda proveniente da circulação do capital (fundos de consumo individual $)^{3}$.

Como último determinante da circulação do capital, podemos citar a emergência do capital de comércio de dinheiro, que é uma parte do capital que se autonomiza no cumprimento de funções estritamente técnicas da circulação do dinheiro. Esse capital executa, para outros capitais, as tarefas

(2) Marx afirma que o fundamento do dinheiro enquanto meio de circulação, ou seja, enquanto mercadoria que cumpre a função de equivalente geral, é de resolver a contradição inerente às mercadorias, que são trabalho abstrato (valor) para o seu produtor, porém numa forma concreta (valor de uso) que não serve às suas necessidades. Na troca simples, existe como condição para que a troca ocorra a coincidência dos valores de uso, no sentido de que as mercadorias trocadas possam suprir as necessidades dos que participam da troca. A função do dinheiro como meio de circulação resolve esta contradição, que é inerente à forma mercadoria.

(3) No Livro II, Marx analisa os fundos de dinheiro formados na circulação do capital industrial. Ao longo dessa circulação, parte do valor gerado pelo capital variável transforma-se em salário, recebido pelos trabalhadores, e a parte do mais-valor gerado que não é reservada para a acumulação ou reposição do capital existente é distribuída para os proprietários do capital. Essas duas fontes são a circulação da renda, que, enquanto entesouradas, devido à questão temporal da realização de compras, formam fundos de consumo individuais. 
de pagamentos, recebimentos, balanço de contas, operações de compensação e guarda do dinheiro na forma de tesouro, que representam custos de circulação do dinheiro. A sua existência está na base do capital bancário, que se forma com a emergência do sistema de crédito, assim como os fundos de reserva estão na base do surgimento do crédito bancário ${ }^{4}$.

O terceiro determinante decorre do capital-dinheiro tornar-se, ele mesmo, uma mercadoria, podendo ser cedido por seu proprietário a outro, como "mercadoria capital" . Ao invés de ser trocado por equivalente, o preço da mercadoria capital é o juro, que corresponde à parte do mais-valor que pode ser obtido com a aplicação deste capital dinheiro de empréstimo. Marx demonstra que surge aí separação do lucro total entre juro, que corresponde à propriedade do capital-dinheiro, e lucro empresarial, que corresponde ao capital em função ativa. A parte relativa ao juro é definida pela oferta e demanda por capital-dinheiro de empréstimo disponível.

O capital cedido como capital de empréstimo e ao qual se paga juros é chamado por Marx de capital portador de juros. A forma de capital portador de juros apresenta uma circulação aparentemente irracional ${ }^{6}$ (D - D'), no qual o adiantamento do capital-dinheiro aparece como responsável pela obtenção, pelo proprietário do capital, de capital-dinheiro em magnitude superior à adiantada. Essa circulação esconde a mediação necessária de obtenção de mais-valor através de aplicação do capital como capital industrial ou comercial. Com isso, aparece como atributo natural do dinheiro a capacidade de valorizar-se e obter juros, como "dinheiro que gera mais dinheiro, valor que se valoriza a si mesmo sem o processo intermediário que liga os dois extremos" (Marx, 2014b, p. 519). A consequência é que há a completa reificação da relação capitalista: o juro parece ser fruto de uma mera coisa, e não resultado de relações sociais específicas ou do processo de trabalho.

Com a figura do capital portador de juros, com a concepção de que o juro é fruto natural e inato de todo capital, Marx explica como todo rendimento periódico de dinheiro, independentemente

(4) O capital bancário é uma forma de capital que tem suas raízes no capital de comércio de dinheiro (Marx, 2014b, p. 534). Com o desenvolvimento do modo de produção capitalista, necessariamente a atividade do capital de comércio de dinheiro deve se ampliar. Com ela, ampliam-se também os fundos monetários, que são a parte do capital que necessariamente deve assumir a forma de capital-dinheiro durante o processo de reprodução. Com o desenvolvimento do capital bancário, está nas mãos dos banqueiros a guarda destes fundos monetários formados pela circulação capitalista, assumindo a forma de tesouro. Além disso, os banqueiros estão encarregados da realização das operações técnicas de receber dinheiro e pagar, efetuar pagamentos internacionais, etc. No entanto, o capital bancário diferencia-se essencialmente do capital de comércio de dinheiro na medida em que os tesouros guardados nos bancos assumem a forma de capital de empréstimo, sendo função particular dos banqueiros a administração desse capital portador de juros na forma de capital-dinheiro de empréstimo (Marx, 2014b, p. 534).

(5) Com a produção capitalista, o dinheiro pode se transformar em capital, assumir a forma de capital-dinheiro, de valor que se expande a partir da produção e apropriação de mais-valor. Nesse caso, o dinheiro adquire um novo valor de uso, que é de funcionar como capital, gerando lucros (Marx, 2014b, p. 453). Esse novo atributo do dinheiro, de ser capital em potencial, permite que o capital se torne, ele mesmo, mercadoria. Isso significa que o proprietário do capital pode, na produção capitalista, alienar o valor de uso do capital-dinheiro de funcionar como capital. Surge, a partir disso, a mercadoria capital (Marx, 2014b, p. 467). A natureza de mercadoria do capital decorre desse seu novo valor de uso, do fato de conservar e ampliar seu valor no processo de circulação, quando é cedido a um terceiro e retorna posteriormente, e de ser dotado de um preço: o juro.

(6) A circulação D - D' apresenta o ponto de partida da circulação do capital, o capital-dinheiro, e o seu ponto de chegada, o valor aumentado, acrescido de mais-valor, mas não apresenta a mediação desse processo através das relações de produção e circulação. Por isso, trata-se de uma forma irracional. Nela, abrevia-se o movimento do capital e omite-se o processo intermediário. Marx afirma que "é a fórmula primitiva e geral do capital, concentrada numa síntese vazia de sentido. O capital em sua marcha completa é unidade do processo de produção e do de circulação, proporcionando por isso determinado mais-valor em período dado. Na forma do capital produtor de juros, esse resultado aparece diretamente, sem a intervenção dos processos de produção e de circulação. O capital aparece como fonte misteriosa, autogeradora do juro, aumentando a si mesmo" (Marx, 2014b, p. 520). 
de sua fonte, passa a ser visto como "juro de um capital". Surge assim a figura do capital fictício, como um capital ilusório cujo valor pode ser obtido através da capitalização dos fluxos de rendimentos futuros esperados mediante uma taxa média de juros. O capital fictício pode tanto representar algo que não é originalmente capital quanto algo que é capital efetivo, existindo previamente como capital efetivo. O valor fictício do capital apresenta um movimento autônomo, decorrente dos fluxos esperados e do movimento da taxa de juros, reforçando a aparência de que a valorização do capital está dissociada do processo de trabalho, reforçando-se a ideia de ser o capital autômato que se valoriza por si mesmo.

Por fim, o quarto determinante do dinheiro são os elementos básicos constitutivos do sistema de crédito: o crédito comercial, o crédito bancário, o dinheiro de crédito e a emergência de um mercado de ações e títulos.

O crédito comercial surge da função de meio de pagamento do dinheiro, quando os diversos produtores e comerciantes compram e vendem a prazo, fazendo com que o pagamento pelas mercadorias que circulam seja protelado. Este fundamento simples é, para Marx, a base do sistema de crédito. As dívidas que se formam nesse processo, formalizadas juridicamente de diversas formas, conforme sua natureza, são agregadas por Marx na categoria de letras, que nada mais são que promessas escritas de pagamento em determinado prazo. As letras veiculam a circulação de mercadorias, compondo o crédito comercial, podendo as letras servir como meio de circulação, sendo repassadas na aquisição de mercadorias mediante endosso, e como meio de pagamento, quando são quitadas mediante a compensação de dívidas. Esse processo acelera a circulação das mercadorias, mas depende sempre do refluir do dinheiro para a liquidação das letras nos seus vencimentos quando os pagamentos não se compensam.

As letras, por cumprirem funções de meio de circulação e, quando se compensam, de meio de pagamento, podem ser consideradas uma forma de dinheiro de crédito, que é a forma do dinheiro que é criada privadamente, pelos agentes da produção e do comércio, mediante a circulação e a compensação das dívidas. É um instrumento que o sistema de crédito gera para si mesmo, superando, na circulação, a necessidade de existência metálica do dinheiro.

A emergência do capital bancário ocorre com o desenvolvimento do crédito bancário e com a guarda, pelos bancos, dos fundos de reserva formados na circulação do capital ativo (industrial e comercial). Transformando essas reservas em capital de empréstimo, o capital bancário assume a função de administrar a massa de capital-dinheiro de empréstimo disponível, ganhando, para isso, parte dos juros, na forma de spread bancário, garantindo a valorização do seu capital ${ }^{7}$. A fonte do capital-dinheiro são os depósitos bancários, formando-se contas correntes de depositários no banco, enquanto o capital-dinheiro é emprestado nas diversas formas de crédito bancário, tais como o desconto de letras e outros adiantamentos de dinheiro (empréstimos bancários). Numa operação de desconto, o banco realiza a compra de letras, creditando ao seu detentor o montante correspondente ao valor das letras menos os juros (o desconto); aquelas letras que não são honradas pelos seus emissores na data de seu vencimento devem ser honradas pelo seu antigo detentor, mediante endosso. Dessa forma, por meio do desconto bancário, o crédito comercial e o crédito bancário se entrelaçam, formando um encadeamento de dívidas e descontos capaz de acelerar o processo de reprodução. No

(7) "Em geral, seu lucro consiste em tomar emprestado a juro mais baixo que aquele a que empresta" (Marx, 2014b, p. 535). 
caso do empréstimo bancário, o capital-dinheiro disponível é adiantado como capital portador de juros, o que pode ocorrer de diversas formas. Parte dos depósitos dos bancos forma o fundo de reserva dos bancos que, com o desenvolvimento do sistema de crédito, fica armazenado em um Banco Central na forma de depósitos em uma conta de reserva.

Com o crédito bancário, desenvolve-se o dinheiro de crédito na forma de bilhetes de banco (notas bancárias). Os bilhetes de banco nada mais são que letras emitidas contra o próprio banco, pagáveis ao portador a qualquer momento em dinheiro efetivo (ouro). Os bancos que emitem bilhetes de banco são chamados de bancos emissores. Assim como as letras, os bilhetes de banco circulam como meio de compra e meio de pagamento, substituindo o dinheiro metálico. Na maioria dos países, os bancos emissores de bilhetes têm por trás de si o crédito nacional, ou seja, o crédito do Banco Central, cujos bilhetes têm curso legal, garantido pelo Estado (Marx, 2014b, p. 536). Como dinheiro de crédito, apresenta um valor fictício por ser mero título, e seu valor é proveniente de ser símbolo de dinheiro real, título representativo de ouro: "o próprio dinheiro de crédito só é dinheiro na medida em que representa absolutamente o dinheiro real no montante de seu valor nominal" (Marx, 2014b, p. 681).

Além do desenvolvimento do crédito comercial e bancário, desenvolve-se no sistema de crédito um mercado organizado de ações e títulos (Bolsa de Valores). As ações são títulos de propriedade do capital e, a partir de seus dividendos distribuídos periodicamente, são capital fictício, tendo seu valor fictício definido pela capitalização desses rendimentos. Esses títulos decorrem de sociedades por ações, em que a propriedade do capital se separa completamente do capital em função. Com as transações de ações e títulos existindo em quantidade e magnitude cada vez maior, desenvolvem-se grandes mercados financeiros concentrados, em que acontecem as compras e vendas de títulos de propriedade. A consequência é a emergência de uma classe rentista e capitalistas prestamistas que operam meramente nessas compras e vendas, vivendo dos rendimentos de seu capital portador de juros aplicado e dos ganhos e perdas associados a compras e vendas, à medida que varia a cotação desses títulos, tornando-se a Bolsa inerentemente um espaço de jogo e especulação, em que o resultado dessas apostas se torna a forma normal de obter e apropriar-se de capital (Marx, 2014b, p. 633).

\section{Os ciclos industriais e as suas fases}

Os ciclos industriais são típicos da produção capitalista principalmente porque nela se desenvolve o sistema de crédito, ao contrário de outros modos de produção. Os ciclos são compostos por fases sucessivas de estagnação, estabilidade, prosperidade, superprodução e especulação, e crise. A crise é inerente ao ciclo e é resultado da própria dinâmica a que o crédito submete a produção capitalista, sendo "o conflito desencadeado entre todos os elementos do processo burguês de produção" (Marx, 2014b, p. 726). Portanto, o sistema de crédito apresenta como consequência, para a dinâmica capitalista, a geração de crises periódicas. Este fato ocorre devido à aceleração da reprodução capitalista para além da realização das mercadorias e do retorno do dinheiro decorrente de suas vendas, ocasionando superprodução impulsionada pelo crédito.

Marx apresenta a sua teoria dos ciclos industriais paralelamente à discussão acerca das crises que ocorrem no período de desenvolvimento da indústria inglesa, entre 1815 e 1870 (Marx, 2014b, 
p. 663). Essas crises podem ser explicadas pela teoria dos ciclos industriais por ele elaborada. Sustentamos aqui a hipótese de que, apesar de Marx realizar uma exposição paralela do processo histórico inglês e da teoria dos ciclos industriais, esta última não constitui um modelo históricoindutivo, formado pela experiência histórica observada por Marx, mas sim de uma teoria derivada do desdobramento lógico das suas categorias abstratas mais complexas, relativas ao sistema de crédito. Nos termos do método da economia política (Marx, 2011; 2008b), pode-se dizer que a interpretação feita por Marx da experiência inglesa nada mais é do que o "retorno ao concreto", em que se compreende o concreto não mais como na esfera da aparência, como um emaranhado incompreensível de relações que escondem seus verdadeiros fundamentos, mas como um todo composto por múltiplas determinações, mediadas pelas categorias abstratas derivadas do próprio concreto. Portanto, o que Marx realiza é uma interpretação histórica a partir das categorias e relações desvendadas por ele no nível da abstração ${ }^{8}$.

O que se observa é que se sucedem diversas crises durante esse período, que ocorreram em 1825, 1837 e 1839, 1847 e 1857 (Marx, 2014b, p. 739). Há também a crise de 1866-67, que não foi incorporada ao Livro III de $O$ Capital, uma vez que os manuscritos ali publicados foram redigidos por Marx em 1864, mas foi tratada por este autor em outros manuscritos, conforme mostram De Paula, Cerqueira et al. (2015). Essas crises estudadas por Marx estão associadas aos ciclos industriais, com periodicidade decenal e caracterizados pela sucessão de fases, associadas aos movimentos da acumulação do capital real e do capital-dinheiro.

No período de depressão, a produção cai abaixo do nível alcançado no ciclo anterior e para o qual existe base técnica. Na prosperidade - o período médio - prossegue desenvolvendo-se nessa base. No período de superprodução e de especulação, as forças produtivas se expandem ao máximo, ultrapassando os limites capitalistas do processo de produção

Portanto, esses ciclos caracterizam-se por expansão gradual da produção até a crise. Na fase de crise e durante a estagnação que dela decorre, cai a produção a nível inferior ao existente anteriormente. No entanto, quando se atinge novamente a fase de prosperidade, o nível da produção já é o mesmo que o existente no ponto mais alto do ciclo anterior e, quando o crédito estimula novamente a superprodução e a especulação, o máximo atingido pela produção supera o máximo atingido no ciclo anterior (Marx, 2014b, p. 646) ${ }^{9}$. Assim, o caráter contraditório da produção capitalista se apresenta aqui como expansão da acumulação que amplia gradualmente a capacidade produtiva, mas que também acarreta necessariamente crises.

Comentando esses ciclos existentes na Inglaterra, Engels ressalta que, após 1867, essa periodicidade decenal deixou de ser a forma usual com que se apresentam os ciclos. Ele ressalta que

(8) É necessário ressaltar que não se trata também de exercício hipotético-dedutivo, uma vez que as categorias de Marx derivam do concreto. O seu método consiste na passagem da aparência para a essência dos fenômenos concretos mediante abstração de suas determinações.

(9) “A estatística das exportações e importações serve para medir a acumulação do capital real - o capital produtivo e o capitalmercadoria. E revela sempre que no período de desenvolvimento da indústria inglesa (1815-1870) marcado por ciclos decenais, o máximo da última fase de prosperidade antes da crise reaparece sempre como mínimo da subsequente fase de prosperidade, para em seguida atingir novo máximo mais elevado" (Marx, 2014b, p. 663). 
o desenvolvimento dos meios de transporte e de comunicação foram responsáveis pela estruturação do mercado mundial e que isto alterou a dinâmica da produção capitalista ${ }^{10}$.

Embora a periodicidade das crises tenha se alterado pelo desenvolvimento do modo de produção capitalista, permanece válida a relação existente na teoria de Marx entre o sistema de crédito e a geração de crises mediante impulsão da produção para além das possibilidades de valorização. Portanto, é necessário compreender a dinâmica que se estabelece entre o crédito e a acumulação do capital-dinheiro e as passagens das diversas fases do ciclo, acarretando crises periódicas e inevitáveis. Conforme Engels, "todo fator que se opõe à repetição das velhas crises traz consigo o germe da crise futura muito mais violenta" (Marx, 2014b, p. 646).

As fases presentes no ciclo industrial são as seguintes: (1) estagnação; (2) estabilidade; (3) prosperidade; (4) superprodução e especulação; e (5) crise. Conforme afirma Marx (2014b, p. 646), "caracteriza esse ciclo industrial a circunstância de, após o primeiro impulso, reproduzir-se necessária e periodicamente o mesmo circuito". Portanto, a fase de estagnação na qual se inicia o ciclo é a fase que sucede a crise do ciclo anterior. Ao mesmo tempo, toda crise se apresenta como ponto de início para novo crescimento, em um novo ciclo e com nível de produção superior ao anterior. Trataremos de explicar o que ocorre em cada fase do ciclo e como o crédito ocasiona esta dinâmica.

\subsection{Estagnação}

A fase de estagnação, na qual se inicia o ciclo industrial, decorre sempre da crise do ciclo anterior. Portanto, nessa fase de "ressaca", nesse "período melancólico", a atividade comercial se encontra em baixa. Consequentemente, o crédito comercial é baixo. Há, portanto, escassez de crédito no comércio, caracterizado pela precaução na venda a crédito e pelo fato de que só se aceitam pagamentos em dinheiro. Consequentemente, a quantidade de letras circulando é baixa.

Perturbada a expansão dos negócios ou mesmo a intensidade normal do processo de reprodução, sobrevém escassez de crédito; fica mais difícil obter mercadorias a crédito. Mas a exigência de pagamento de contado e a precaução na venda a crédito caracterizam particularmente a fase do ciclo industrial que sucede o craque (Marx, 2014b, p. 639).

Nesse período, devido à desaceleração da produção e da circulação, caem os preços das mercadorias e decorre disso que, do meio circulante em poder do público, ou seja, dos bilhetes de banco emitidos pelo Banco Central ${ }^{11}$, a maior parte se encontra como encaixe nos bancos, entesourados devido à baixa circulação efetiva ${ }^{12}$, o que ocorre mesmo com a baixa velocidade de

(10) "Depois da crise geral de 1867 sobrevieram grandes modificações. Na realidade, foi a expansão colossal dos meios de transporte e comunicações - navios a vapor, ferrovias, telégrafo elétrico, canal de Suez - que estruturou o mercado mundial. Vários países industriais surgiram ao lado da Inglaterra, que antes monopolizava a indústria; em todas as partes do mundo, abriram-se mais vastos e mais diversificados territórios à aplicação do capital europeu excedente, que desse modo se reparte mais amplamente, superando com mais facilidade os excessos de especulação locais. Todos esses fatores suprimiram ou enfraqueceram bastante, na maior parte, os antigos focos e as conjunturas responsáveis pelas crises" (Marx, 2014b, p. 646).

(11) No caso concreto analisado por Marx, que é o contexto da Inglaterra no Século XIX, o Banco da Inglaterra exercia algumas funções consideradas funções típicas de um banco central, como a emissão centralizada de bilhetes de banco (garantida a partir da Lei Bancária de 1844), a manutenção de contas de reserva de outros bancos ingleses e a manutenção de reservas em ouro como dinheiro mundial.

(12) "Se os preços das mercadorias caem, se diminuem as transações, se o capital desembolsado em salários se contrai, fica sendo menor a quantidade necessária de meios de circulação" (Marx, 2014b, p. 641). 
circulação que marca este período. Não só o crédito é reduzido, como a própria reprodução do capital se desacelera. As compras e vendas permanecem em baixa (em ritmo lento) como decorrência da crise e o dinheiro permanece entesourado nos bancos. Consequentemente, o período de estagnação apresenta uma redução na circulação do capital industrial e um excesso de capital-dinheiro disponível, indicando a discrepância entre a acumulação do capital real (capital produtivo e capital-mercadoria) e a acumulação do capital-dinheiro ${ }^{13}$.

Capitais de empréstimo se amontoam ociosos após a crise, e isso decorre da produção restringida acompanhada pela contração do crédito. A baixa circulação, com número reduzido de transações e menores preços, leva a uma menor necessidade de meio circulante, e o excesso de bilhetes em poder do público fica entesourado nos bancos, formando maior massa de capital-dinheiro de empréstimo. Juntamente a isso, decorre dessa retração do capital industrial uma baixa procura por capital de empréstimo. Essa menor demanda se expressa, em primeiro lugar, em quantidade reduzida de letras que são descontadas, e, em segundo lugar, pelo menor número de empréstimos. $\mathrm{O}$ crédito comercial reduzido faz com que a circulação de letras seja baixa e, consequentemente, por decorrência do reduzido volume de letras, haja baixa demanda por operações de desconto (Marx, 2014b, p. 641). A demanda por capital-dinheiro de empréstimo na condição de meio de circulação e de meio de pagamento também é baixa devido à retração da circulação, e, quando se trata de demanda para novos investimentos de capital, esta é ainda menor (Marx, 2014b, p. 641). "Nessas circunstâncias, a oferta de capital-dinheiro de empréstimo aumenta positivamente" (Marx, 2014b, p. 641-642).

Influi ainda para que os períodos de estagnação sejam marcados por excesso de capitaldinheiro disponível o fato de que cessam as evasões de ouro, pois, durante a crise, se liquida a maior parte das dívidas existentes com o exterior. "Se foram liquidadas as dívidas ao estrangeiro, seja pela exportação de ouro, seja por meio de falências, não é necessário dinheiro adicional algum para exercer a função de dinheiro mundial" (Marx, 2014b, p. 641). Assim, a fase de estagnação não é marcada pela saída de ouro, mas pelo reestabelecimento do encaixe do Banco Central a partir da importação de ouro (Marx, 2014b, p. 757). "Embora na época de prosperidade exista forte reserva em ouro no Banco da Inglaterra, esse encaixe se forma sempre na fase de apatia e estagnação que segue à tempestade" (Marx, 2014b, p. 603). Com isso, a oferta de capital-dinheiro também se amplia, pois afeta positivamente os encaixes depositados pelos bancos particulares.

Como consequência dessa massa de capital-dinheiro disponível e da baixa procura existente por esse capital nos momentos em que a produção se restringe, a taxa de juros atinge o seu patamar mínimo. "Nesses momentos, quando o processo de produção se restringe, é baixa a taxa de juros reinante, o que apenas constitui índice de ter acrescido o capital para empréstimo em virtude de contrair-se e paralisar-se o capital industrial" (Marx, 2014b, p. 641).

(13) Marx discute as diferenças entre o que chama de "acumulação de capital real" (maior ou menor volume de capital produtivo e capital-mercadoria) e "acumulação de capital-dinheiro" (maior ou menor oferta de capital-dinheiro de empréstimo disponível) no contexto do debate com a escola de pensamento do Currency Principle, principalmente com referência à teoria e às declarações de Lorde Overstone. Marx critica Overstone por confundir acumulação de capital-dinheiro, o capital disponível dos bancos e cuja oferta relativa reflete-se na taxa de juros, com a acumulação de capital real, justificando juros altos por "escassez de capital real". A partir disso, Marx discute as diferenças acerca desses dois fenômenos ao longo das fases do ciclo industrial, com o claro intento de demonstrar que não se trata da mesma coisa e que a concepção de Overstone e dos demais teóricos do Currency Principle está equivocada, ou seja, "desmascarar a sabedoria interessada de Overstone de que o dinheiro é 'caro' por ser 'raro' o capital” (Marx, 2014b, p. 733). 


\subsection{Estabilidade}

O período de estabilidade é caracterizado pela retomada lenta e gradual da acumulação de capital industrial. O que incentiva esta retomada é justamente a baixa taxa de juros, pois, com ela, aumenta a parte da taxa geral de lucro que se converte em lucro do empresário. Com isso, impulsionase o processo de reprodução e, gradualmente, a produção aumenta e os retornos passam a fluir mais facilmente. Com os lucros obtidos pelos capitais industriais em alta e com vendas crescendo, os preços das mercadorias e os salários passam a subir, acompanhando a expansão da atividade industrial, que inicia um novo ciclo de acumulação ${ }^{14}$. Com retornos fáceis, sustentados pelos lucros, expande-se gradualmente o crédito comercial. Os capitalistas industriais e comerciantes passam a emitir letras com mais frequência, comprando e vendendo a prazos mais longos. Decorre disso que passam a descontar essas letras nos bancos, porém em baixa quantidade, pois ainda não dependem do crédito bancário para obter retorno em dinheiro de suas atividades. Nessa fase de melhora dos negócios decorrente dos juros baixos, "o crédito comercial, ainda andando com os próprios pés, só moderadamente precisa do crédito bancário” (Marx, 2014b, p. 646).

Com a expansão da atividade, maior número de transações e aumento gradual dos preços, amplia-se a necessidade de meio circulante (Marx, 2014b, p. 698). Nesta fase, assim como ocorre na fase de estagnação, tende a ocorrer maior importação de ouro do que nas demais, pois não se demanda ouro como meio de pagamento internacional, (Marx, 2014b, p. 757) ${ }^{15}$. Além disso, o crédito bancário também passa a crescer, devido à busca por meios de circulação, através dos descontos de letras, e por capital-dinheiro para a ampliação da produção. Portanto, toma-se aqui emprestado não buscando meios de pagamento para saldar dívidas, mas sim meios de compra:

Em épocas de reanimação após a crise, procura-se capital de empréstimo para comprar e para transformar o capital-dinheiro em capital produtivo ou comercial. Então pedem-no tanto o capitalista industrial quanto o comerciante. O capitalista industrial emprega-o em meios de produção e em força de trabalho (Marx, 2014b, p. 677).

No entanto, nessa fase, o capital-dinheiro de empréstimo disponível continua abundante, apesar do crescimento gradual do crédito. Esse crédito bancário expandido ainda é baixo em relação à oferta de capital de empréstimo, principalmente porque a expansão do capital industrial se sustenta principalmente com o crédito comercial fornecido pelos próprios capitalistas industriais e comerciantes, e o crédito bancário só é demandado de maneira secundária. Além disso, este período é caracterizado por haver maior tendência de importação de metais preciosos, o que expande as reservas dos bancos. Como consequência, ainda há abundância de capital de empréstimo, porém, com

(14) "A ampliação do processo real de produção é incentivada porque a taxa de juro baixa, que no primeiro caso [fase de estagnação] coincide com preços baixos e no segundo [fase de estabilidade] com preços em ascensão lenta, aumenta a parte do lucro que se converte em lucro de empresário" (Marx, 2014b, p. 656).

(15) "A importação de metal precioso ocorre sobretudo em duas fases. Na fase de juro baixo, a primeira que segue à crise e expressa produção restringida, e na segunda fase em que o juro sobe, mas sem ter atingido ainda o nível médio. É nesta fase em que os retornos se operam facilmente, o crédito comercial é grande, e por isso a procura de capital de empréstimo cresce na medida em que se expande a produção. Em ambas as fases, com capital de empréstimo relativamente abundante, a afluência suplementar de capital na forma de ouro e prata - forma que só lhe permite a função de capital de empréstimo - deve influir consideravelmente na taxa de juro, e, por conseguinte, na marcha geral dos negócios" (Marx, 2014b, p. 757). 
o aumento da procura, aumenta a taxa de juro. Esse aumento é lento e a taxa tende a se manter, nessa fase, abaixo da média durante o ciclo.

Nessa fase, o juro continua baixo, embora se eleve acima do mínimo. [...] A facilidade e a regularidade dos retornos, conjugadas com crédito comercial expandido, asseguram a oferta de capital de empréstimo, apesar da procura acrescida, e impedem que se eleve a taxa de juro. (Marx, 2014b, p. 645).

Esta fase do ciclo industrial e a seguinte são as únicas que conjugam expansão efetiva do capital industrial e abundância de capital de empréstimo, refletida na baixa taxa de juro, pois, em geral, "o movimento do capital de empréstimo, expresso na taxa de juro, se efetua em sentido inverso ao do capital industrial” (Marx, 2014b, p. 645).

\subsection{Prosperidade}

$\mathrm{Na}$ fase de prosperidade, a expansão do capital permanece sendo impulsionada pelo elevado lucro do empresário decorrente dos juros baixos, com retomada das vendas. Apesar do crescimento lento que ocorre com a taxa de juro desde a fase anterior, Marx afirma que os lucros do empresário não se reduzem, pois a taxa geral de lucro aumenta em proporção maior do que os juros, possibilitando lucro do empresário superior à fase de estabilidade (Marx, 2014b, p. 656). Com isso, o processo de acumulação de capital real é continuado e expandido. Permanece a tendência do retorno fácil do dinheiro que expande o crédito comercial: "nesses tempos de prosperidade, o retorno se dá fácil e suave. O comerciante a retalho paga certo ao atacadista, este ao fabricante, este ao importador das matérias-primas, etc." (Marx, 2014b, p. 597). Assim, não há problemas em se emitir ou se aceitar letras, e esta prática se torna a regra do comércio:

Quando o processo de reprodução de novo atinge fase de prosperidade que precede à de tensão extrema, alcança o crédito comercial extensão muito grande, que volta realmente a repousar na base "sólida" de retornos fáceis de dinheiro e de produção expandida (Marx, 2014b, p. 645).

Assim, a expansão do crédito comercial se sustenta na produção expandida e na certeza de que as letras serão pagas em seu vencimento. "Enquanto o processo de reprodução mantém a fluidez e assim assegura o retorno do capital, esse crédito perdura e se expande, e essa expansão é baseada sobre a do próprio processo de reprodução" (Marx, 2014b, p. 638).

Com aceleração do processo de acumulação de capital real assentada na expansão do crédito comercial e na manutenção de elevadas taxas de lucro, amplia-se a procura por capital-dinheiro de empréstimo para o capital industrial, na forma de capital constante e capital variável. Com isso, tendem a subir os preços das mercadorias e os salários ${ }^{16}$ e aumenta a procura por capital-dinheiro de empréstimo e, consequentemente, eleva-se a taxa de juros.

Todavia, aumentando a procura de capital variável, cresce a de capital-dinheiro, provocando alta da taxa de juro. O preço de mercado da força de trabalho sobre então acima da média, emprega-

(16) Aqui, Marx demonstra como, especificamente na fase de prosperidade, pode haver aumento do lucro e dos salários. No entanto, o aumento dos salários nunca é causa de aumento da taxa de lucro, e sim de sua queda: "aumento de salário nunca é causa da elevação do lucro, embora, considerando-se fases especiais do ciclo industrial, possa ser uma de suas consequências. [...] a procura ascendente de força de trabalho, portanto de capital variável, de per si não aumenta o lucro, mas o reduz de quantidade correspondente" (Marx, 2014b, p. 677-678). 
se número de trabalhadores superior à média, e ao mesmo tempo eleva-se a taxa de juro, pois nessas circunstâncias aumenta a procura de capital-dinheiro. A procura crescente de força de trabalho encarece essa mercadoria como acontece a qualquer outra, elevando o preço dela, mas não o lucro, que se baseia sobretudo no preço relativo baixo justamente dessa mercadoria. Mas, ao mesmo tempo, - nas condições estabelecidas - ela faz subir a taxa de juro, por aumentar a procura de capital-dinheiro (Marx, 2014b, p. 678).

A fase de prosperidade, portanto, é marcada pela expansão do crédito bancário decorrente da maior demanda por capital-dinheiro de empréstimo, com a taxa de juro retornando ao seu nível médio (Marx, 2014b, p. 645). Realizam-se operações de desconto e de adiantamentos com facilidade e os lucros obtidos pelas firmas são elevados. O crédito facilitado amplia os capitais de terceiros adiantados às firmas e aumentam as suas obrigações perante os bancos. Operar com base no crédito em geral torna-se a norma do comércio.

Surge então em cena número considerável de embusteiros que trabalham sem capital de reserva, sem qualquer capital, operando totalmente na base do crédito monetário. Acresce aí grande expansão do capital fixo em todas as formas e a fundação em massa de novas e vastas empresas. (Marx, 2014b, p. 645).

Nessa fase ainda, avançam no mesmo sentido expansivo os movimentos do capital real e do capital-dinheiro de empréstimo, embora esteja perto o ponto de virada, com progressiva escassez relativa do capital-dinheiro, expressa numa crescente taxa de juros, que ultrapassará seu nível médio.

Amplia-se a velocidade de circulação do dinheiro, principalmente pelo estado do crédito em alta, em que depósitos se tornam rapidamente empréstimos. Com isso, cada vez mais as funções de circulação são efetuadas por meras transferências de crédito, sem intervenção de moeda metálica ou de bilhetes de bancos.

Nesse período, a quantidade de meio circulante existente para satisfazer as necessidades da circulação da renda se torna relativamente maior do que para a circulação do capital. Isso ocorre porque, com a alta dos salários, impulsionados pela demanda por capital variável, e com a alta dos lucros, devido ao maior lucro do empresário, as rendas se ampliam e, consequentemente, o consumo. Realizam-se, portanto, mais transações envolvendo o consumo individual de mercadorias, demandando meios de circulação. Além disso, os preços das mercadorias sobem regularmente durante o período de prosperidade. Assim, ampliam-se as transações como consequência não só do aumento da circulação de mercadorias e de valores, mas também devido aos preços mais elevados. Decorre disso que aumenta a quantidade de dinheiro em termos absolutos na circulação da renda, porém limitada pelo aumento da velocidade de circulação do dinheiro (Marx, 2014b, p. 595-6). "O resultado final é que nos períodos de prosperidade acresce a massa dos meios de circulação que serve para dispêndio de renda" (Marx, 2014b, p. 596).

Por outro lado, quando se trata da circulação do capital, é necessário considerar que a fase de prosperidade é o "tempo de crédito mais elástico e fácil" (Marx, 2014b, p. 596). Nesta esfera da circulação, é o crédito que regula a velocidade do dinheiro:

Massas maiores de pagamentos são liquidadas sem interferência de dinheiro; com a grande animação do processo, predomina movimento mais rápido das mesmas quantidades de dinheiro, 
Henrique de Abreu Grazziotin, Ronaldo Herrlein Jr.

tanto na função de meio de compra quanto na de meio de pagamento. Mesma massa de dinheiro possibilita o retorno de número maior de capitais individuais (Marx, 2014b, p. 596).

Dessa forma, segundo Marx, a circulação do capital industrial apresenta contração pelo menos relativa da quantidade de meio circulante, devido ao fato de que o crédito poupa aí meios de circulação em grau maior que na circulação da renda.

Ao todo, a circulação de dinheiro nesses períodos de prosperidade está em sua plenitude, embora a parte II (transferência de capital) se contraia pelo menos relativamente, enquanto a parte I (dispêndio de renda) se expande em termos absolutos (Marx, 2014b, p. 596).

Portanto, a prosperidade é marcada pelo crédito em sua plenitude, com os retornos do crédito comercial sustentados pelo próprio processo de reprodução e com o crédito bancário com elevada demanda, fazendo com que a taxa de juros atinja o seu nível médio. A partir disso, toda produção capitalista é impulsionada por um sistema de dívidas cuja base monetária para saldá-las se estreita cada vez mais.

\subsection{Especulação e superprodução}

Marca o período de superprodução e especulação existência de excesso de dívidas sobre o capital próprio das firmas. Os capitalistas industriais e comerciais se apoiam cada vez mais na atividade do desconto de letras para adiantar suas receitas e aplicar o capital novamente na produção, assim como na capacidade de tomar empréstimos. Todo o processo de reprodução se sustenta no crédito durante esse período. Surgem cada vez mais firmas e agentes que operam exclusivamente com o crédito, ou seja, com capital de terceiros, tendo capital próprio irrisório. Exemplos são os corretores de letras:

No período de especulação, cada vez mais os bill-brokers efetuam operações sem reserva em numerário, fiando-se no pagamento das letras que descontam, que se venciam progressivamente, e também na capacidade de tomar empréstimos caucionados nestas letras nos bancos. (Marx, 2014b, p. 628).

Nessa fase, a circulação de letras se amplia enormemente, passando a atividade de descontar essas letras a ter papel crucial na reprodução. Por meio do crédito bancário, adianta-se cada vez mais o retorno do capital-mercadoria com base em expectativas favoráveis devido à inflação dos preços (Marx, 2014b, p. 648). Nesse sentido, especula-se cada vez mais com os resultados futuros da produção: a aposta de que os ganhos continuem crescendo é o que alavanca a produção, que cresce sustentada no crédito. No entanto, enquanto prossegue a acumulação de capital real, o capital-dinheiro se torna relativamente mais escasso.

A consequência do elevado endividamento e da dependência do crédito nas operações das firmas é a escassez de capital-dinheiro de empréstimo. As reservas dos bancos se tornam cada vez menores à medida que se amplia a procura por capital-dinheiro para descontos e adiantamentos e isso pressiona a taxa de juros, fazendo-a subir acima da média (Marx, 2014b, p. 645). Portanto, a especulação baseada nos resultados futuros e apoiada pelo crédito faz com que a taxa de juro supere seu nível médio e mantenha trajetória de crescimento, na medida que se aprofunda a redução do capital-dinheiro de empréstimo disponível. 
Com o aumento gradual dos juros, elevam-se as taxas de desconto e se torna cada vez mais difícil antecipar os retornos em dinheiro. Além disso, os juros altos têm como consequência a queda do lucro do empresário. Decorre disso que as firmas com alto grau de endividamento passam a se encontrar em situação de crescente fragilidade e buscam, cada vez mais, rolar as suas dívidas, pagando-as com capital alheio. Caso passem a existir dificuldades de se obter retornos das vendas das mercadorias, generaliza-se a prática de emitir letras sem fundamento na venda de mercadorias ("letras frias"), apenas com o objetivo de descontá-las e obter capital alheio, o que Marx (2014b, p. 532) chama de "papagaios". O aprofundamento dessas práticas é o resultado da especulação que caracteriza essa fase do ciclo.

Alta taxa de juro pode ser paga com alta taxa de lucro, embora decresça o lucro do empresário. Pode ser paga - e isso acontece às vezes em épocas de especulação - não com o lucro, mas com o próprio capital alheio emprestado, o que pode persistir por algum tempo (Marx, 2014b, p. 677).

Como podem tomar crédito para sanar sua situação, a aparência geral da reprodução não é de dificuldade e de crise iminente, mas sim de sustentação do crescimento. Assim, uma característica da fase de especulação excessiva é que, com o crédito mantendo-se ativo, apesar da pressão sobre ele exercida e que se reflete no aumento da taxa de juros, permanece a aparência de retornos rápidos e seguros mesmo depois de deixarem de ser reais (Marx, 2014b, p. 597). Os retornos sustentados pelo crédito representam os verdadeiros e escondem a crise latente e o crédito é capaz de manter a aparência de atividade em alta. No entanto, "os bancos começam a desconfiar quando os clientes depositam mais letras que dinheiro" (Marx, 2014b, p. 597).

Entretanto, o processo inteiro se complica tanto - com a emissão de meros papagaios, ou com negócios de mercadorias destinados apenas a fabricar letras - que pode subsistir a aparência tranquila de negócio sólido e de retornos fáceis de dinheiro, quando há muito tempo esses retornos na realidade só se fazem mediante fraude contra prestamistas ou contra produtores. Por isso, sempre às vésperas do craque, os negócios aparentam quase solidez extrema [...] Os negócios vão muito bem, reina a maior prosperidade, e de repente surge a catástrofe (Marx, 2014b, p. 640641).

Outro fator importante para a manutenção da aparência de retornos sólidos durante a fase de superprodução e para a existência de uma defasagem entre o surgimento de problemas na reprodução e a eclosão da crise, é a relação existente entre o capital industrial e o capital comercial (Marx, 2014a, p. 86-87). Devido à separação entre produção e consumo, mediada pelo capital comercial, pode ser que haja estoques acumulados de mercadorias invendáveis. Permanece a aparência para o capital industrial de que o ciclo de reprodução continua normalmente, mas a superprodução já assola o mercado e as condições para a crise já estão dadas.

Assim, pode aumentar a produção do mais-valor e, com ele, o consumo individual do capitalista [industrial], encontrar-se em pleno progresso todo o processo de reprodução, e, apesar disso, grande parte das mercadorias ter entrado na esfera da circulação apenas na aparência, continuando na realidade armazenada nas mãos dos revendedores sem ser vendida, retida, portanto, no mercado. Uma remessa de mercadoria sucede a outra, para se verificar no fim que a remessa anterior apenas aparentemente foi absorvida pelo consumo (Marx, 2014a, p. 87). 
A relação entre o capital industrial e comercial é importante principalmente no comércio internacional, em que há a venda das mercadorias a exportadores e importadores. A atividade especulativa realizada especificamente no âmbito do comércio internacional tem repercussão importante para o ciclo, uma vez que a expansão desenfreada do capital industrial leva à existência de superprodução, ou seja, produção para além da capacidade de absorção da coletividade mediante a realização das mercadorias. Em contexto de superprodução e abarrotamento dos mercados, as mercadorias se tornam invendáveis e os preços das mesmas caem. Esta queda dos preços e a dificuldade em vender inviabilizam os retornos em dinheiro das firmas altamente endividadas e, consequentemente, prejudica o fluxo de pagamento das letras emitidas. Os balanços de pagamentos das nações se tornam desfavoráveis devido à necessidade de pagar as dívidas do comércio internacional com meio de pagamento internacional, ou seja, dinheiro metálico. Isso tem como consequência a saída de ouro dos países em que ocorre superprodução, afetando as reservas do Banco Central e dos bancos particulares, ou seja, a base monetária sobre a qual se sustenta todo o sistema de crédito. Portanto, o processo de superprodução se manifesta no comércio internacional e, devido ao excesso de letras vencidas, provoca saída de ouro que abala a estrutura do crédito. Esse "gatilho" da crise apresentado por Marx é o que exploraremos a seguir. Conforme afirma Marx, é na fase de especulação e superprodução do ciclo que ocorre saída contínua de ouro, afetando todo o sistema.

Êxodo, grande exportação contínua de metal precioso, dá-se quando as receitas não mais se convertem em dinheiro, os mercados estão abarrotados e a prosperidade aparente só se mantém ainda por meio do crédito; isto é, quando já existe procura de capital de empréstimo muito acrescida e por isso a taxa de juro já alcançou pelo menos o nível médio (Marx, 2014b, p. 757).

A superprodução para o comércio internacional se expressa no fato de que, entre os países que se envolvem na crise, o balanço de pagamentos se torna desfavorável a todos, o que é um sintoma de terem todos importado e exportado demais com base no crédito e nos preços ascendentes das mercadorias. ${ }^{17}$ Esse excesso de exportação e importação nada mais é que sintoma da superprodução (Marx, 2014b, p. 648-649).

Como decorrência da superprodução, o abarrotamento dos mercados torna as mercadorias invendáveis, fazendo com que caiam os preços e se dificultem os retornos. Consequentemente, nessa fase, os países necessitam saldar suas dívidas, o que ocorre, segundo Marx, de forma sucessiva, um país após o outro, provocando saídas de ouro demandado como meio de pagamento internacional, vendas de mercadoria a preços muito baixos ou então falências dos devedores, que acabam tendo que se desfazerem de seu capital para pagar as letras a vencer. O balanço de pagamentos desfavorável, portanto, corresponde ao ajuste das contas decorrente do excesso de crédito, e provoca evasão de metais, processo que ocorre sucessivamente nos países relacionados, enquanto sintoma da superprodução, e representa um ajuste da estrutura de obrigações das firmas.

Em tempos de crise geral, o balanço de pagamentos é desfavorável a toda nação, pelo menos a toda nação comercialmente desenvolvida, mas sempre uma após a outra, como num fogo por filas, de acordo com a vez de pagar; e a crise, uma vez irrompida na Inglaterra, por exemplo, concentra a série de pagamentos que se vencem em período extremamente curto. Patenteia-se

(17) "Um após outro, todos os países se envolvem na crise, verificando-se que todos, com poucas exceções, exportaram e importaram demais, ficando o balanço de pagamentos desfavorável a todos: é que a crise de fato não provém do balanço de pagamentos" (Marx, 2014b, p. 648). 
então que todas essas nações se excederam ao mesmo tempo nas exportações (vale dizer na produção) e nas importações (no comércio, portanto), que em todas os preços foram impelidos para cima e exagerou-se no crédito. E em todas sucede o mesmo descalabro. O fenômeno da saída de ouro então ocorre a todas, uma após outra, e em virtude da generalidade revela (1) que a hemorragia de ouro é mero sintoma da crise e não causa dela, e (2) que a sucessão em que sobrevém às diversas nações apenas mostra a ordem em que estas ajustam as contas com os céus, a ocasião em que surge a fase decisiva da crise e se desencadeiam os elementos latentes dela. (Marx, 2014b, p. 649-650).

Dessa maneira, pode-se perceber que, para Marx, a evasão de ouro que caracteriza essa fase do ciclo não é meramente um fenômeno nacional, mas envolve diversos países através do comércio e do crédito. Trata-se de um sintoma da crise por vir, pois é a esfera na qual primeiro se manifesta o problema da superprodução: "O êxodo de metal é em regra sintoma de mudança da situação do comércio exterior, e essa mudança, por sua vez, prenuncia que estão amadurecendo as condições da nova crise" (Marx, 2014b, p. 757). A demanda por ouro "surge no momento exato em que os mercados externos estão abarrotados de capital-mercadoria inglês invendável" (Marx, 2014b, p. 601). Trata-se, portanto, de "sinal do colapso já iniciado",

[...] indicação de mercados abarrotados, de que cessa a procura estrangeira de nossos produtos, de que se atrasam os pagamentos, sendo consequência necessária de tudo isso o descrédito comercial, o fechamento de fábricas, a fome entre os operários e a paralisação geral da indústria e dos negócios (Marx, 2014b, p. 603).

A saída de metal atua como fator decisivo sobre a base fragilizada do crédito. Há escassez de capital-dinheiro de empréstimo e, em decorrência, a taxa de juros é elevada. A evasão de ouro impacta o sistema de crédito, em primeiro lugar, "por ter o metal precioso o caráter específico de capital na forma dinheiro" e, em segundo lugar, por agir "como a pena que, posta num dos pratos oscilantes da balança, inclina-a a seu favor" (Marx, 2014b, p. 758). Assim, o dinheiro em sua existência metálica, por ser o eixo do sistema de crédito, impacta este sistema ao se esvair como meio de pagamento internacional. No entanto, isso ocorre apenas porque esta base já se encontra fragilizada na fase de especulação e superprodução do ciclo industrial.

Sem esses motivos seria totalmente incompreensível que uma evasão de ouro de 5 a 8 milhões de libras esterlinas, e esse é o máximo até hoje verificado pela experiência, pudesse ter qualquer efeito importante; essa ínfima quantidade de capital, acrescentada ou subtraída, que se patenteia insignificante mesmo em face dos 70 milhões de libras esterlinas em ouro que em média circulam na Inglaterra, é grandeza evanescente numa produção com o volume da inglesa (Marx, 2014b, p. 758-759).

Portanto, na tensão extrema imposta ao sistema de crédito nessa fase do ciclo, qualquer evasão de ouro se torna decisiva para a eclosão da crise. Inclusive, é possível que a saída de ouro que inicia a crise decorra de um transtorno súbito da produção, como, por exemplo, excesso de importação decorrente de má colheita e escassez de produtos agrícolas. Assim, podem ocorrer choques que nada têm a ver com a superprodução em si, mas que, se ocorrem na fase de tensão do ciclo, podem desencadear a crise (Marx, 2014b, p. 759). 


\subsection{Crise}

A evasão de ouro atinge o encaixe de ouro do Banco Central, impactando as suas reservas e as reservas dos bancos particulares. A consequência disso é o alarme dos banqueiros em relação ao seu capital de empréstimo disponível: restringe-se o crédito e continua a aumentar a taxa de juros. Como consequência, quando eclode a crise, a taxa de juros atinge o seu nível máximo durante o ciclo. A escassez de crédito faz com que o processo de reprodução se estanque, gerando capital real (capital produtivo e capital-mercadoria) estagnado, sem aplicação ou destinação.

[A taxa de juro] volta a atingir o nível máximo, quando irrompe a nova crise, quando o crédito cessa de súbito, estancam os pagamentos, paralisa-se o processo de reprodução e, com as exceções antes mencionadas, surge, ao lado da escassez quase absoluta de capital de empréstimo, pletora de capital industrial desocupado (Marx, 2014b, p. 645).

A reprodução do capital industrial, que mantinha sua aparência de retornos seguros exclusivamente através dos adiantamentos permitidos pelo crédito bancário, agora perde sua base ilusória de sustentação com a escassez de crédito e com os juros elevados. A elevação da taxa de juros reduz o lucro empresarial e o absorve por completo em certos ramos de atividade e para certos capitais individuais (Marx, 2014b, p. 664), de modo que "a taxa de lucro e com ela a procura de capital industrial praticamente desaparecem" (Marx, 2014b, p. 677). Com essa baixa taxa de lucro, portanto, sobrevém a crise e se estanca completamente o processo de acumulação de capital, reduzindo-se de imediato a demanda por capital constante e por capital variável. Trata-se de paralisação geral do processo de reprodução. Na crise "cada um tem de vender e não pode comprar, precisando vender para pagar" as suas dívidas. Como consequência, "fecham-se as fábricas, as matérias-primas se amontoam, os produtos acabados são mercadorias que abarrotam o mercado" (Marx, 2014b, p. 639).

Essa paralisação geral da reprodução acontece porque existe, na crise, capital produtivo em excesso, pletora de capital industrial (Marx, 2014b, p. 639). Isso nada mais é que superprodução decorrente da impulsão dada pelo sistema de crédito ao capital industrial. As suas consequências são a formação de estoques de mercadorias invendáveis, a derrubada dos preços das mercadorias e a impossibilidade do pagamento das letras.

Quando os negócios estancam, por se retardarem os retornos de capital, por se abarrotarem os mercados, por caírem os preços, há tal pletora de capital industrial que ele não pode desempenhar sua função. Amontoam-se massas invendáveis de capital-mercadoria. O capital fixo está em grande parte desocupado em virtude de estagnar-se a reprodução (Marx, 2014b, p. 639).

A discrepância entre os movimentos da acumulação do capital real e da acumulação do capital monetário alcança nesse momento um nível extremo.

Assim, a queda dos preços do capital-mercadoria é mero sintoma da superprodução. O elemento causador dessa queda é a acumulação excessiva de capital industrial. Essa queda tem como consequência impossibilitar o pagamento das letras que se vencem, pois os capitalistas não obtém o retorno necessário para saldar essas dívidas. $\mathrm{O}$ abarrotamento dos mercados proporcionado pela superprodução derruba os preços, contraindo o capital-dinheiro potencial representado nas mercadorias. O capital-dinheiro que se pode obter com sua venda se torna insuficiente para saldar as 
letras emitidas para a sua produção ou aquisição ${ }^{18}$. Assim, o capital-mercadoria com menor preço "representa para o possuidor e para o credor deste (e como garantia de letras e empréstimos) menos capital-dinheiro que ao tempo em que foi adquirido e em que, por ele garantidos, se efetuaram descontos e empréstimos" (Marx, 2014b, p. 648).

Com a paralisação do capital industrial em excesso, se estanca também o crédito comercial. Ele naturalmente se contrai, já que o capital industrial está parado, desocupado, sem poder completar sua metamorfose (Marx, 2014b, p. 639). De forma geral, é afetada a confiança em relação aos pagamentos, porque o processo de reprodução é incerto e não se sabe se, ao vender a crédito, se receberá o pagamento (Marx, 2014b, p. 639). No entanto, essa questão não é tão relevante pelo fato de que a procura por crédito comercial diminui absolutamente: "o fabricante de fios que reduz a produção e tem estoque invendável não precisa comprar algodão a crédito; o comerciante não necessita comprar mercadorias a crédito, pois delas já tem mais do que carece" (Marx, 2014b, p. 639).

Durante a crise, a escassez de crédito bancário, por sua vez, atinge nível extremo e deixa de sustentar as letras sem base. Torna-se difícil descontar letras e, se isso se faz, é a custo muito alto, por causa das taxas de desconto em seu maior nível ${ }^{19}$. Com o crédito restringido, admitem-se apenas pagamentos em dinheiro (ouro ou bilhetes de banco), o que ocasiona corrida violenta aos meios de pagamento (Marx, 2014b, p. 647). Há uma grande quantidade de letras a vencer e os devedores não possuem dinheiro para saldá-las. No entanto, essas letras representam transações reais que ocorreram em contexto de superprodução e os retornos não são suficientes para o pagamento.

Num sistema de produção em que o mecanismo de reprodução repousa sobre o crédito, se este cessa bruscamente admitindo-se apenas pagamento de contado, deve evidentemente sobrevir crise, corrida violenta aos meios de pagamento. Por isso, à primeira vista, toda crise se configura como simples crise de crédito e crise de dinheiro. E, na realidade, trata-se apenas da conversibilidade das letras em dinheiro. Mas essas letras representam, na maioria dos casos, compras e vendas reais, cuja expansão ultrapassa as longas exigências da sociedade, o que constitui, em última análise, a razão de toda a crise (Marx, 2014b, p. 647).

$\mathrm{Na}$ crise, esse montante de letras incapaz de ser saldado não passa de capital fictício sem nenhuma base de realização. "Massa enorme dessas letras representa especulações puras que desmoronam à luz do dia; ou especulações conduzidas com capital alheio, porém malsucedidas" (Marx, 2014b, p. 647). Elas não são mais do que representação de "capitais-mercadorias que se depreciaram ou ficaram mesmo invendáveis, os retornos irrealizáveis de capital" (Marx, 2014b, p. 647).

A escassez de crédito tem como consequência a emergência de pânico financeiro, que está relacionado à busca incessante por meios de pagamento para saldar as letras no seu vencimento. Esse pânico emerge quando o Banco Central eleva sua taxa de desconto de letras em período de crise. A partir disso, generaliza-se o receio quanto ao futuro e, com isso, "todo mundo, e em primeiro lugar os

(18) Marx ressalta o fato de que a queda dos preços das mercadorias apenas compensa a inflação dos preços que ocorre no período anterior: "se tem esse sentido a afirmação de que se reduz o capital-dinheiro de um país em épocas de crise, significa ela que os preços das mercadorias caíram. Aliás, esse desmoronamento dos preços apenas compensa a inflação anterior" (Marx, 2014b, p. 648).

(19) "A primeira dificuldade é descontar letra ou obter adiantamento com penhor de mercadoria. É dificuldade para converter em dinheiro-capital ou um valor comercial que representa capital. E essa dificuldade expressa-se, entre outras coisas, pela alta taxa de juro" (Marx, 2014b, p. 574). 
que especulam e jogam com o crédito, procura descontar o futuro e ter à disposição, no momento adequado, tanto quanto possível de meios de crédito" (Marx, 2014b, p. 758).

Durante o pânico financeiro que ocorre nas crises, o objetivo dos especuladores é "obter meios de pagar as letras sacadas sobre ele e vencidas, tendo em conta a carência de crédito e a fim de não ter que liquidar suas mercadorias abaixo do preço" (Marx, 2014b, p. 569). Portanto, no período de crise, o que falta é dinheiro em sua função de meio de pagamento (Marx, 2014b, p. 646). Decorre disso que a demanda por capital-dinheiro de empréstimo não cessa na crise, mas apenas muda de caráter: deixa de ser demanda por dinheiro na função de meio de compra para ser dinheiro na função de meio de pagamento. Não se toma empréstimos ou se desconta letras com o objetivo de repor a produção, e muito menos para realizar projetos de ampliação da capacidade produtiva. O que se busca são meios de liquidar dívidas (Marx, 2014b, p. 677).

Em época de crise, a procura de capital de empréstimo é procura de meios de pagamento e nada mais; de modo nenhum é procura de dinheiro como meio de compra. A taxa de juro pode então subir muito, não importando que haja excesso ou escassez de capital real - capital produtivo e capital mercadoria (Marx, 2014b, p. 680).

Ao mesmo tempo em que a procura por meios de pagamento atinge o máximo, impõe-se uma dificuldade aos capitalistas que deles precisam: o período de crise é caracterizado por imenso entesouramento de dinheiro, seja na forma de ouro ou de bilhetes de banco. Isso ocorre tanto pelo receio dos capitalistas que possuem bilhetes acerca do futuro, quanto pelo fato de que se estanca o crédito bancário. Os banqueiros, com receio de que as letras a descontar não sejam pagas no vencimento ou de que o capital-dinheiro de empréstimo não retorne ao seu bolso, estancam descontos e outros adiantamentos. Dessa forma, quando mais se precisa de bilhetes de banco, mais difícil é obtêlos. Sobre isso, Marx (2014b, p. 698) cita o banqueiro Wright, que afirma que "durante o pânico o país precisa duas vezes mais bilhetes em circulação que em tempos normais, pois os banqueiros e outros os entesouram".

Dessa forma, o pânico financeiro se mostra uma dança das cadeiras do mercado de dinheiro: há mais letras vencidas do que dinheiro para saldá-las, e os meios de pagamento que existem são entesourados pelos banqueiros e pelos particulares, com receio quanto ao futuro. Os que não conseguem obter meios de pagamento devem vender mercadorias a preços irrisórios ou desfazer-se de seu capital para pagar suas dívidas. No limite, declara-se falência.

Em relação ao meio circulante durante a crise, pode-se dizer que diminui enormemente a circulação de dinheiro na função de meio de compra e aumenta a circulação na função de meio de pagamento. "Em épocas de crise toma-se adiantamento para pagar e não para comprar; para concluir negócios anteriores e não para iniciar novos" (Marx, 2014b, p. 609). Dessa forma, a massa global de meio de circulação pode variar, dependendo do quanto a magnitude da redução do dinheiro na função de meio de compra pode compensar o aumento da circulação de dinheiro como meio de pagamento. Assim, o meio de circulação pode tanto ficar estável e diminuir como também pode aumentar (Marx, 2014b, p. 609). Além disso, é necessário ressaltar que, no período de crise, a divisão do meio circulante entre a circulação da renda e a circulação do capital se inverte em relação ao período de prosperidade. Contrai-se enormemente a circulação da renda, uma vez que os preços caem, os salários caem, há menor número de trabalhadores ocupados e reduz-se a quantidade de transações (Marx, 
2014b, p. 597). A circulação do capital, por sua vez, se amplia relativamente devido à escassez do crédito: maior quantidade de meios de pagamento na forma de bilhetes de banco circula para saldar as dívidas vencidas (Marx, 2014b, p. 597).

Por fim, é necessário apontar as implicações da crise na Bolsa de Valores, na cotação das ações e nos preços dos títulos. Assim como o capital-mercadoria, os títulos que são capital fíctício e que são forma do capital portador de juros também representam capital-dinheiro potencial. Na crise, seus preços caem fortemente por dois motivos: o primeiro é o aumento da taxa de juros, e o segundo é o aumento da oferta de ações e títulos no mercado (Marx, 2014b, p. 650-651). Devido à escassez geral de crédito, os detentores de títulos os colocam à venda para obter dinheiro como meio de pagamento para suas dívidas.

As ações, além disso, têm o seu preço ainda mais reduzido caso haja queda dos rendimentos esperados da ação na forma de dividendos. Portanto, se os títulos representam capitais efetivos cuja realização de mais-valor é atingida por perturbações no processo de reprodução e cujos rendimentos se reduzem, há nova baixa nos valores de mercado. A variação do preço de mercado desses títulos na Bolsa pode ser resumida como segue:

Em tempos de crise no mercado de dinheiro, esses títulos experimentam dupla baixa: primeiro, por que o juro sobe e, segundo, porque se lançam em massa no mercado, para serem convertidos em dinheiro. Essa queda de preço se verifica tanto no caso de ser constante o rendimento que esses títulos asseguram ao proprietário, como acontece com os títulos da dívida pública, quanto no caso de a produção de mais-valor do capital efetivo que representam ser atingida eventualmente pelas perturbações do processo de reprodução, ocorridas em empresas industriais. Neste caso, os títulos retornam ao nível anterior, desde que não representem negócios malogrados ou fraudulentos (Marx, 2014b, p. 620).

Evidentemente, a queda das cotações das ações e dos preços dos títulos, embora não tenha nenhum efeito sobre o valor do capital real que representam, impacta diretamente a solvência de seus proprietários. Ao venderem os títulos, o capital-dinheiro adquirido é inferior ao capital-dinheiro potencial representado pelos títulos antes da crise, quando tinham preços de mercado mais elevados. Ao mesmo tempo, esses títulos afetam o poder de seus proprietários de tomarem empréstimos caucionados, pois o capital-dinheiro que representam se torna muito baixo (Marx, 2014b, p. 651).

Durante a crise, a depreciação desses títulos atua de forma a centralizar poderosamente a riqueza financeira. Grandes capitalistas prestamistas de dinheiro, rentistas e especuladores podem comprar os títulos a preços muito baixos, uma vez que seus detentores necessitam obter dinheiro para pagamentos. Se adquirem ações, então o capital se concentra após a crise. Quando se normaliza a situação e a taxa de juro volta a cair, esses títulos recuperam seus preços. ${ }^{20}$ Se seus compradores os mantêm após a crise, terá se concentrado a propriedade do capital ao final do ciclo. Se os vendem, então terão obtido montante maior de capital-dinheiro meramente pela especulação com o preço do título.

(20) "A taxa de juro atinge seu nível mais alto nas crises, quando, para pagar, se tem que tomar emprestado a qualquer preço. Acarretando a alta do juro queda no preço dos títulos, têm então as pessoas que dispõem de capital-dinheiro excelente oportunidade para se apropriarem, a preços vis, desses papéis rentáveis, que necessariamente recuperarão pelo menos o preço médio quando a situação se normalizar e o juro de novo cair" (Marx, 2014b, p. 480). 
Por fim, a Figura 1 apresenta a trajetória da taxa de juro ao longo do ciclo industrial.

Figura 1

A taxa de juro ao longo do ciclo industrial

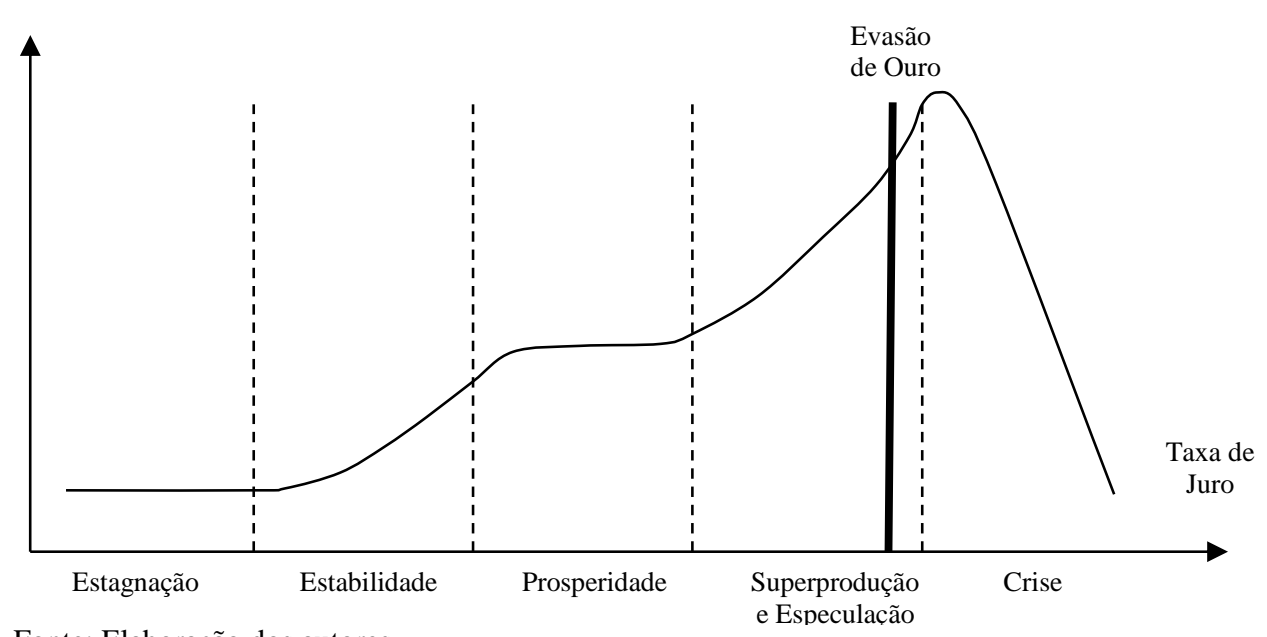

Fonte: Elaboração dos autores.

\section{Conclusão}

Este trabalho teve como objetivo apresentar uma sistematização da teoria dos ciclos industriais de Marx, caracterizando cada etapa do ciclo e explicitando as relações existentes entre o sistema de crédito e a acumulação do capital industrial. Para isso, apresentamos primeiramente os determinantes do dinheiro na teoria monetária de Marx, de forma a introduzir os elementos teóricos básicos para a compreensão da dinâmica descrita por Marx nos ciclos industriais. Buscamos realizar essa sistematização a partir da seção V do Livro III de O Capital, reorganizando os argumentos ali presentes a fim de reconstruir esta parte de sua teoria, que, ainda hoje, é muito pouco explorada na literatura marxista.

O ciclo industrial descrito por Marx segue as seguintes fases: estagnação, crescimento, prosperidade, superprodução/especulação e crise. Na fase de estagnação, que é a fase que segue à crise do ciclo anterior, há paralisação do capital industrial, excesso de capital-dinheiro disponível e baixa demanda por crédito comercial e por crédito bancário, estando a taxa de juros, nessa fase, no patamar mínimo observado ao longo do ciclo. Na fase de crescimento, há a recuperação gradual dos negócios impulsionada pelo lucro empresarial elevado decorrente da baixa taxa de juros. Com isso, amplia-se gradualmente o crédito comercial. No entanto, ainda é baixo crédito bancário, elevando-se lentamente a taxa de juros. Na fase de prosperidade, a taxa de juros atinge seu nível médio ao longo do ciclo, com a expansão do capital industrial e do crédito comercial e bancário. Na fase de superprodução e especulação, a reprodução capitalista deixa de ter a sua base na realização das mercadorias e passa a calcar-se cada vez mais no crédito. Passa-se a depender cada vez mais do crédito bancário, na forma de descontos de letras e empréstimos, para a acumulação do capital industrial, especulando-se com a capacidade futura de realização das mercadorias produzidas. Na descrição de Marx, a etapa de crise se inicia com a evasão de divisas internacionais decorrentes da 
necessidade de pagamentos de dívidas internacionais geradas no comércio, que abalam o sistema de crédito e iniciam a restrição do crédito bancário. Com isso, há busca por capital-dinheiro de empréstimo na função de meio de pagamento, como forma de pagar as dívidas a vencer, o que tem como consequência o pico da taxa de juros ao longo do ciclo.

Dentre os diversos aspectos tratados por Marx em sua descrição dos ciclos industriais, há dois que merecem destaque: o primeiro envolve a descrição de Marx sobre os movimentos cíclicos das taxas de juros decorrentes da dinâmica da acumulação do capital industrial. Assim, há uma explicação sobre as flutuações das taxas de juros decorrentes da dinâmica entre oferta e demanda de capitaldinheiro de empréstimo, que estão associadas à paralisação ou aceleração do capital industrial. $\mathrm{O}$ segundo envolve o fato de que, em determinado momento, a acumulação do capital industrial deixa de estar fundamentada nos retornos dos pagamentos das mercadorias e passa a ser sustentada pelo sistema de crédito, estando aí já dados os elementos constitutivos da crise por vir.

Essa sistematização aqui apresentada demonstra como há, inegavelmente, em Marx, uma teorização acerca de crises endógenas impulsionadas pelo sistema de crédito, nas quais há a geração periódica de superprodução e de pânico financeiro, com corrida aos meios de pagamentos, restrição de crédito por parte do capital bancário e insolvência para pagamento de dívidas decorrentes da reprodução capitalista. Uma vez verificada a relevância desta concepção teórica, é necessária sua incorporação aos debates teóricos marxistas acerca das causas das crises em economias capitalistas e o seu aprofundamento, no sentido de incorporar o desenvolvimento contemporâneo do sistema de crédito internacional e das finanças no capitalismo avançado.

\section{Referências bibliográficas}

CIPOLLA, F. P. Interest rate changes in Marx's theory of the industrial cycle. International Journal of Political Economy, Issues in Marxian Theory of Money and Credit, v. 27, n. 1, p. 73-84, 1997.

CROTTY, J. The role of money and finance in Marx's crisis theory. In: CHERRY, R. et al. (Ed.). The imperiled economy: macroeconomics from a left perspective. New York: Union for Radical Political Economics, 1987.

DE BRUNHOFF, S. Marx on money. New York: Urizen Books, 1976. 139p.

DE PAUlA, J. A., CERQUEIRA, H. E. G. et al. Investigating financial innovation and stock exchanges: Marx, the notebooks on the crisis of 1866 and structural changes in capitalism. Belo Horizonte: UFMG/CEDEPLAR, 2015. 46p. (Texto para Discussão, n. 515).

FOLEY, D. Money, accumulation and crisis. New York: Harwood Academic Publishers, 1986.

GERMER, C. M. Credit money and the functions of money in capitalism. International Journal of Political Economy - Issues in Marxian Theory of money and Credit, v. 27, n. 1, p. 43-72, 1997.

GERMER, C. M. Componentes estruturais da teoria do dinheiro no capitalismo contemporâneo. Revista da Sociedade Brasileira de Economia Política, v. 1, n. 1, p. 106-133, 1997.

HARVEY, D. Os limites do capital. São Paulo: Boitempo, 2013. 590p. 
Henrique de Abreu Grazziotin, Ronaldo Herrlein Jr.

HILFERDING, R. Finance capital: a study of the latest phase of capitalist development. Routledge, 1985.

ITOH, M. Value and crisis: essays on Marxian economics in Japan. New York: Monthly Review Press, 1980.

ITOH, M. The basic theory of capitalism: the forms and substance of the capitalist economy. London: Macmillan Press, 1988.

LIANOS, T. P. Marx on the rate of interest. Review of Radical Political Economics, v. 19, n. 3, p. 34$55,1987$.

MARX, K. O capital: crítica da economia política. Livro I - O processo de produção do capital. v. 1. 30. ed. Rio de Janeiro: Civilização Brasileira, 2012.

MARX, K. O capital: crítica da economia política. Livro I - O processo de produção do capital. v. 2. Rio de Janeiro: Civilização Brasileira. 1998. 929p.

MARX, K. O capital: crítica da economia política. Livro II - O processo de circulação do capital. v. 3. 14. ed. Rio de Janeiro: Civilização Brasileira. 2014a. 598p.

MARX, K. O capital: crítica da economia política. Livro III - O processo global de produção capitalista. v. 4. Rio de Janeiro: Civilização Brasileira. 2013a.

MARX, K. O capital: crítica da economia política. Livro I - O processo de produção do capital. São Paulo: Boitempo, 2013b. 894p.

MARX, K. O capital: crítica da economia política. Livro III - O processo global de produção capitalista. v. 5. 2. ed. Rio de Janeiro: Civilização Brasileira, 2014b.

MARX, K. O capital: crítica da economia política. Livro II - O processo de circulação do capital. São Paulo: Boitempo, 2014c. 766p.

MARX, K. Contribuição à crítica da economia política. São Paulo: Expressão Popular. 2008b. 285p.

MARX, K. Grundrisse: manuscritos econômicos de 1857-1858. São Paulo: Boitempo, 2011. 788p.

SHERMAN, Howard. The business cycle: growth and crisis under capitalism. Princeton, NJ: Princeton University Press, 1991.

WEEKS, John. Capital and exploitation. Princeton, NJ: Princeton University Press, 1981. 